\title{
LEFTY1 wt Allele
}

National Cancer Institute

\section{Source}

National Cancer Institute. LEFTY1 wt Allele. NCI Thesaurus. Code C52012.

Human LEFTY1 wild-type allele is located in the vicinity of 1q42.1 and is approximately 3 $\mathrm{kb}$ in length. This allele, which encodes left-right determination factor B protein, plays a role in left-right asymmetry determination of organ systems during development. 